\title{
A god for guts
}

\section{BACKGROUND}

While attending the 15th National Conference on Advances in Perinatal and Paediatric Nutrition at the University of Stanford, California, July 2001, at an evening social event at the Cantor Center for Visual Arts, I chanced upon the small but remarkable collection of ancient Egyptian artefacts from the Stanford Family Collection.

\section{CANOPIC JARS}

In the University of Stanford collection of ancient Egyptian artefacts are two alabaster canopic jars dating from the 18th dynasty (1539-1295 BC) at the time of the New Kingdom. One had a head stopper shaped like a falcon (fig l) representing Kebeh-senu-ef, one of the four sons of Horus acting as a guardian god of the embalmed guts of the deceased. A very similar name is given at the British Museum for the same god, namely Qebhsenuef. These four sons of Horus were the genii who guarded the north, south, east, and west. Remarkably, the ancient Maya of central America also had four deities upholding heaven at the four points of the compass. The Maya also used funerary jars called after these gods.

Nunn, ${ }^{1}$ in his remarkable account of ancient Egyptian medicine, states that the embalmers showed great technical expertise removing those internal organs, most likely to putrefy through a relatively small incision. These organs could not be discarded as they could be used to cast spells against the deceased. Furthermore, they had to be adjacent to the body when, as they believed, resurrection occurred in the afterlife. The organs removed were the liver, lungs, stomach, and intestines. Each had a son of Horus as a protector as well as a protective goddess. The goddess for the intestines was Serqet. From the 18th dynasty of Egypt each canopic jar had a head. For the intestines it was described as the falcon (see above) or hawk. ${ }^{1}$ The internal organs were dried in natron (sodium chloride, sulphate, carbonate, and bicarbonate) and placed in the canopic jars. Interestingly, by $700 \mathrm{BC}$ the organs were dried and placed back in the body. Yet canopic jars remained, in fact these were now solid wood and were only there as they had become vital to the funerary assemblage (British $\mathrm{Mu}$ seum exhibit 2001).

\section{ORGAN REMOVAL AT DEATH}

The custom of removing vital organs at death and burying these separately con-

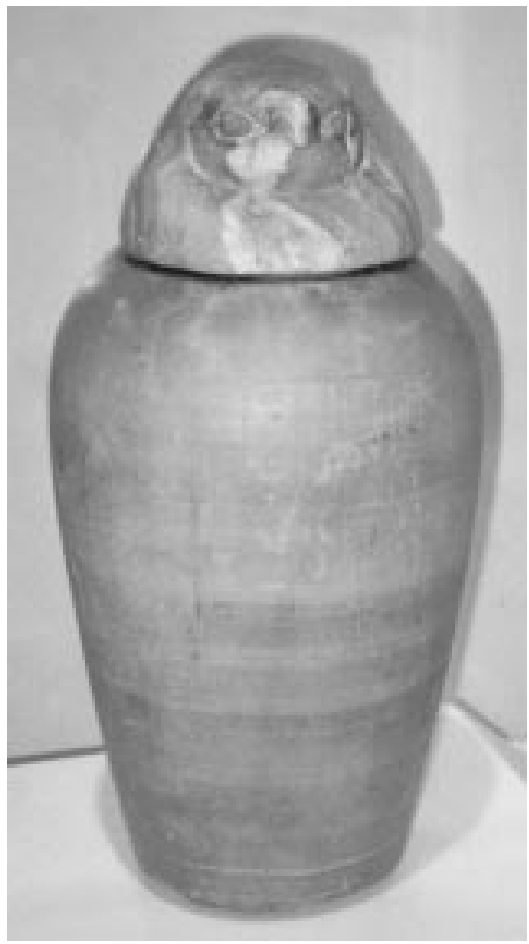

Figure 1 Alabaster canopic jar: Egypt 18th dynasty (1539-1295 BC). The falcon head stopper represents Kebeh-senu-ef, son of Horus, guardian of the embalmed intestines (photographed by the author at University of Stanford, Cantor Center for Visual Arts).

tinued for centuries, especially for royalty. Perhaps the most remarkable case is that of the deposed Stuart King James II (England) and VII (Scotland). His entrails, brain, and heart were all removed and then his body embalmed. Also, flesh was taken from his right arm, pieces of linen were dipped in his blood, and cuttings of his hair preserved. All this was done to provide religious relics of the king who was almost regarded as a saint in Roman Catholic circles. His entrails were divided in two and placed in two urns. ${ }^{2}$ One is still in the church of SaintGermain-en-Laye in Paris and the other, now out of an urn, is at Stonyhurst College. $^{2}$

As recently as 1989, the heart was removed from the body of the last Empress of Austria-Hungary, Zita in Switzerland, where it remains in the monastery of Muri. Her embalmed body was buried in Vienna with the Hapsburgs. ${ }^{3}$ However, her intestines were not removed.

\section{MODERN STUDIES OF REMOVED ORGANS}

Corp $^{2}$ remarks that subjects such as James II who have accessible remains are ideal subjects to study DNA. In the case of the Stuarts this is relevant to the study of the porphyria gene which appears to have been passed down by his grandmother Mary Queen of Scots. Gastroenterologists however are likely to be disappointed as Nunn argues that the state of preservation is too poor to reveal the presence of disease but has the attempt been made? Much is known about bone disease, etc., in ancient Egypt from investigation of mummies.

\section{GASTROENTEROLOGY IN ANCIENT EGYPT}

Knowledge of the internal organs of the body was limited in ancient Egypt. No human dissection was undertaken in Egypt until the Ptolemaic period in the third century BC. This was undertaken by the Greek physician, Herophilus of Chalcedon in Alexandria. Nunn ${ }^{1}$ recalls the words of Celsus (Loeb edition, l Prooemium 23)

"Moreover, as pains, and also
various kinds of disease arise in
the more internal parts, they (the
Rationalists) hold that no one can
apply remedies for these who is
ignorant about the parts
themselves; hence it becomes
necessary to scrutinize their
viscera and intestines."

Extraordinarily, Herophilus probably undertook vivisection of criminals as well as postmortem studies. ${ }^{4}$ Perhaps because of this, after his time human dissection ceased in antiquity.

However, there certainly was a folk awareness that internal organs such as the intestines could be the site of disease. In the British Museum a crude terracotta model of the intestines, Roman in origin and dating from the third to the first century BC, is displayed. Such models of parts of the body were dedicated at shrines of the healing gods in the hope of a cure or as a thank offering for a cure itself. Such votive offerings of simple models of body parts such as legs, eyes, etc, continue in the Orthodox Church to this day.

Nunn ${ }^{1}$ identifies in the hieroglyphic writings a description of a doctor as 
being "a court gastroenterologist" by which he means a royal doctor of the belly or abdomen and also identified a proctologist, literally a herdsman of the anus. Citing from the ancient Egyptian medical papyri, Nunn was able to demonstrate some significant knowledge of gastrointestinal disease by the practising doctors of the time. He states however that it is by no means clear to what extent the embalmers passed on any anatomical knowledge to the doctors as the embalmers themselves were regarded as unclean. He does cite one example of a chief physician of the Middle Kingdom who had a grandfather who was an embalmer.

In Christian times a Bishop of the Church, Saint Erasmus, was identified as patron of gastrointestinal and liver diseases. ${ }^{5}$ He was born in Antioch during the third century and was tortured by being forced to wear copper heated clothing around his abdomen. Later his dominion over the bowels was indicated by images of him holding a spit around which intestines were wrapped. His feast day is still celebrated by both Roman Catholic and Orthodox churches on 2 June.

\section{CONCLUSION}

It is of interest that from ancient times through to the early Christian era the intestines had their sacred protectors or guardians. In ancient Egypt the god for the guts was Qebhseneuf, one of the four guardians of the corners of the world. In the early Christian period, Saint Erasmus became the saint of the guts.
J Walker-Smith,

The Wellcome Trust Centre for the History of Medicine at UCL, University College London, 24 Eversholt St, London NWI IAD, UK; johnwalker_smith@hotmail.com

\section{REFERENCES}

1 Nunn JF. Ancient Egyptian medicine. London: British Museum Press, 2000

2 Corp E. The last years of James II 1690-1701. History Today 2001:51;19-25.

3 Eftychiadis A Chen TS. Saint Erasmus, patron saint of gastrointestinal and liver diseases. J Med Biogr 2001;9:97-8.

4 Nunn JF. Ancient Egyptian medicine. London: British Museum Press, 2000.

5 Jackson R. Doctors and diseases in the Roman Empire. London: British Museum Press, 1988 